\title{
Induction of Tetracycline Resistance in Staphylococcus aureus in the Absence of Lipid Synthesis
}

\author{
By I. CHOPRA \\ Department of Bacteriology, The Medical School, University of Bristol, \\ Bristol BS8 ITD
}

(Received 15 July 1975)

INTRODUCTION

Resistance to tetracycline in Staphylococcus aureus and enteric bacteria is often plasmid determined. The characteristics of plasmid-mediated tetracycline resistance in these bacteria are similar, in that resistance is usually inducible (Izaki, Kiuchi \& Arima, 1966; Franklin, 1967; Sompolinsky et al. 1970a; Franklin \& Cook, I97 I Chopra, Lacey \& Connolly, 1974; Foster \& Walsh, 1974; Shipley \& Olsen, 1974; Asheshov, 1975), and appears to result from decreased uptake of the antibiotic (Izaki et al. 1966; Franklin, 1967; De Zeeuw, 1968; Sompolinsky et al. I970a; Avtalion et al. 197I ; Kuck \& Forbes, 1973; Shipley \& Olsen, I974).

Although the precise mechanism of tetracycline resistance is unknown, these features suggest that the gene products involved in resistance may be similar in all cases. This view is supported by the data of Levy \& McMurry (1974) and Boldur \& Sompolinsky (1974) which indicate that in enteric organisms at least, expression of tetracycline resistance following induction probably results from the insertion of a protein (or proteins) into the envelope. In $S$. aureus, a protein (or proteins) associated with the expression of tetracycline resistance has also been found (Avtalion et al. 197I), but this is undetectable in membrane preparations (Chopra et al. 1974). However, it seems probable that this protein is indeed associated with the staphylococcal membrane in vivo and may be released during membrane isolation (Chopra et al. 1974). This view is supported by the findings of Boldur \& Sompolinsky (1974) which suggest that the proteins associated with tetracycline resistance may only be loosely associated with the membrane in certain organisms.

Studies on the assembly of bacterial membranes have shown that some proteins can be incorporated into the membrane in a functional form in the absence of lipid synthesis (Machtiger \& Fox, 1973; Randall, 1975). Since expression of plasmid-mediated tetracycline resistance probably results from the insertion of proteins into the membrane, it is of interest to know whether or not resistance can be expressed in the absence of lipid synthesis.

\section{METHODS}

Bacteria. Staphylococcus aureus strain UB40 I2, which contains plasmid pUB I I (specifying resistance to tetracycline), has been described previously under the former description 649 tet-r(p) (Chopra et al. I974).

Culture media. These have been described previously (Chopra et al. 1974).

Other materials. Cerulenin was the gift of S. Ōmura. L-3. $\left[\mathrm{G}-{ }^{3} \mathrm{H}\right]$ phenylalanine ( $\mathrm{I} \mathrm{mCi} / \mu \mathrm{mol}$ ) and uniformly-labelled sodium $\left[{ }^{14} \mathrm{C}\right]$ acetate $(59 \mu \mathrm{Ci} / \mu \mathrm{mol})$ were obtained from the Radio- 
chemical Centre, Amersham, Buckinghamshire. Tetracycline hydrochloride (achromycin) was purchased from Lederle Laboratories, London.

Estimation of fatty acid synthesis in whole bacteria. The incorporation of radioactivity from sodium $\left[{ }^{14} \mathrm{C}\right]$ acetate into chloroform-extractable material was used as a measure of fatty acid synthesis. Bacteria were grown in the presence of uniformly-labelled sodium $\left[{ }^{14} \mathrm{C}\right]$ acetate $(0.2 \mu \mathrm{Ci} / \mathrm{ml})$ and $0.8 \mathrm{ml}$ samples of culture extracted at $4{ }^{\circ} \mathrm{C}$ by the method of Bligh \& Dyer (I959). Samples (0.5 ml) of the chloroform phase (containing extracted lipids) were evaporated to dryness in scintillation vials and $5 \mathrm{ml}$ of a scintillation fluid (see Lacey \& Chopra, 1972) added. Radioactivity was estimated in a Packard Tri Carb liquid scintillation spectrometer.

Estimation of protein synthesis in whole bacteria. Bacteria suspended in a nutrient broth containing L-3-[G- $\left.{ }^{3} \mathrm{H}\right]$ phenylalanine $(2 \mu \mathrm{Ci} / \mathrm{ml})$ were incubated with shaking at $37{ }^{\circ} \mathrm{C}$ for various periods. Growth was terminated by the addition of trichloroacetic acid to $5 \%(\mathrm{w} / \mathrm{v})$ and incorporation of radioactivity into protein determined as previously described (Lacey \& Chopra, 1972).

\section{RESULTS}

Cerulenin [(2S) (3R) 2,3,-epoxy-4-oxo-7, I0-dodecadienoylamide] is a specific inhibitor of $\beta$-keto acyl thioester synthetase and therefore interferes both with de novo fatty acid synthesis and with chain elongation from palmityl CoA (D'Agnolo et al. 1973). Addition of cerulenin (I $25 \mu \mathrm{g} / \mathrm{ml}$ ) to growing cultures of UB40 I 2 resulted in virtually complete inhibition of fatty acid synthesis (Fig. Ia), but had little effect on protein synthesis during a period of $40 \mathrm{~min}$ following addition of the antibiotic (Fig. I $b$ ). These results are essentially similar to those obtained by Goldberg, Walker \& Bloch (I973) and Randall (I975), who demonstrated that concentrations of cerulenin sufficient to inhibit lipid synthesis had little immediate effect on protein synthesis in Escherichia coli.

Pre-incubation of UB4OI 2 for 40 min with $5 \mu \mathrm{g}$ tetracycline $/ \mathrm{ml}$ produced a marked fall in the subsequent inhibition of protein synthesis by the antibiotic, compared with organisms grown initially in the absence of drug (Fig. 2). These results are essentially the same as those described previously (Chopra et al. 1974) and represent induction of tetracycline resistance.

Addition of cerulenin (I $25 \mu \mathrm{g} / \mathrm{ml}$ ) during pre-exposure of UB4O I 2 to tetracycline $(5 \mu \mathrm{g} / \mathrm{ml})$ had no effect on the subsequent degree of inhibition of protein synthesis by tetracycline compared with organisms pre-incubated in the presence of tetracycline, but without cerulenin (Fig. 2). Thus, induction of tetracycline resistance appears to occur to the same extent in the absence of lipid synthesis as under normal growth conditions.

\section{DISCUSSION}

Synthesis of membrane proteins in the absence of lipid synthesis could lead to at least three possibilities with respect to their association with the membrane: (i) lack of incorporation into the membrane, (ii) incorporation into the membrane, but in a manner resulting in impairment of functional capacity of the protein, and (iii) integration and correct insertion into the membrane, resulting in full functional capacity. Although there appear to be no examples of membrane proteins that cannot be incorporated into membranes in the absence of lipid synthesis, examples of the situations arising in (ii) and (iii) are known (Machtiger \& Fox, 1973; Randall, 1975).

The data presented here suggest that tetracycline resistance in $S$. aureus can be induced in the absence of lipid synthesis. If, as seems probable, resistance results from insertion of 

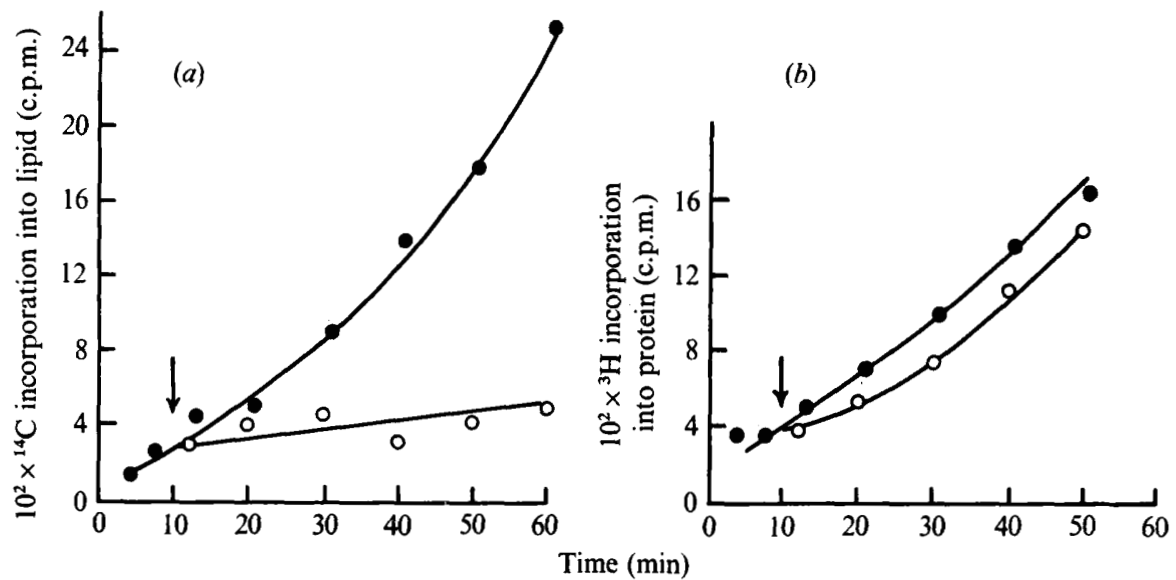

Fig. I. Effect of cerulenin on $(a)$ lipid synthesis and $(b)$ protein synthesis in UB4OI2. Either $(a)$ uniformly-labelled sodium $\left[{ }^{14} \mathrm{C}\right]$ acetate $(0 \cdot 2 \mu \mathrm{Ci} / \mathrm{ml})$ or $(b)_{\mathrm{L}-3}-\left[\mathrm{G}-{ }^{3} \mathrm{H}\right]$ phenylalanine $(2 \mu \mathrm{Ci} / \mathrm{ml})$ were added at time zero to exponentially-growing cultures of UB40I2 (10 $0^{8}$ bacteria $\left./ \mathrm{ml}\right)$. After IO min, cerulenin ( $25 \mu \mathrm{g} / \mathrm{ml}$ ) was added to portions of the labelled bacteria (arrowed) and portions removed at the times indicated for estimation of radioactivity incorporated into lipid and protein in the control (O) and cerulenin-treated $(O)$ cultures.

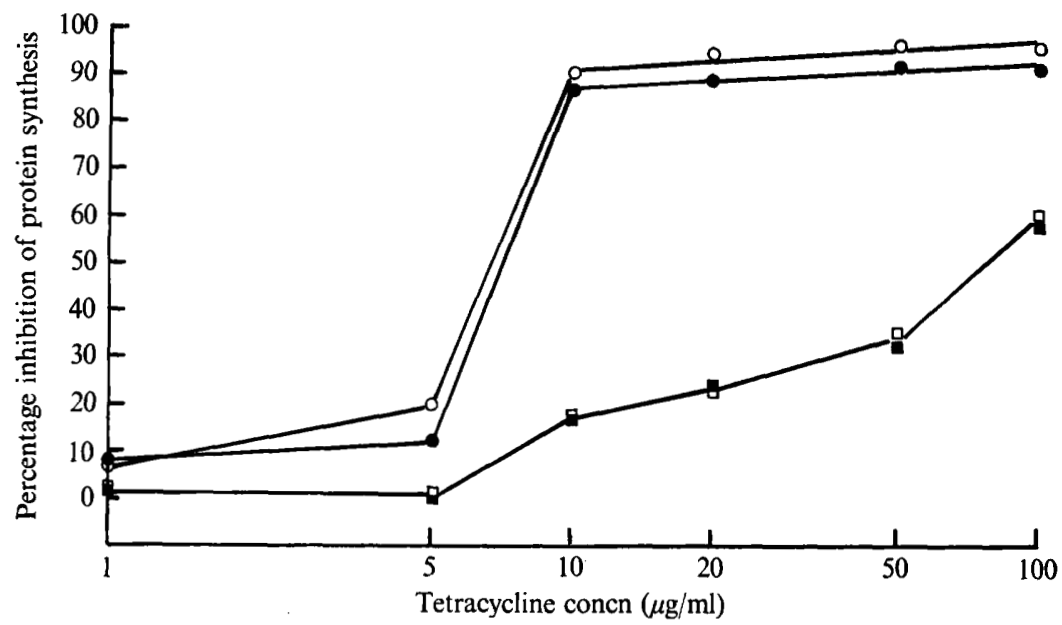

Fig. 2. Effect of cerulenin on induction of tetracycline resistance in UB40I2. Exponential-phase cultures of UB4OI2 ( $10^{8}$ bacteria $/ \mathrm{ml}$ ) were pre-incubated for $40 \mathrm{~min}$ at $37^{\circ} \mathrm{C}$ with $(\square)$ tetracycline $(5 \mu \mathrm{g} / \mathrm{ml})$, with ( $)$ tetracycline $(5 \mu \mathrm{g} / \mathrm{ml})+$ cerulenin $(125 \mu \mathrm{g} / \mathrm{ml})$, with (O) cerulenin (I25 $\mu \mathrm{g} / \mathrm{ml})$, or $(O)$ with no additions. Bacteria were harvested by centrifugation ( $5000 \mathrm{~g}, 10 \mathrm{~min}, 4^{\circ} \mathrm{C}$ ), washed twice in cold nutrient broth, and resuspended in the same medium to give an $E_{675}$ of 0.2 (equivalent to $10^{8}$ bacteria $/ \mathrm{ml}$ in growing cultures). Incorporation of $\mathrm{L}-3-\left[\mathrm{G}-{ }^{3} \mathrm{H}\right]$ phenylalanine $(2 \mu \mathrm{Ci} / \mathrm{ml})$ into protein (during $40 \mathrm{~min}$ ) in the presence of the indicated concentrations of tetracycline was then determined for each culture.

a plasmid-specific protein into the membrane, these results imply that this process can occur normally in the absence of lipid synthesis.

This work was supported by grants from the Medical Research Council to Professor M. H. Richmond for studies on bacterial plasmids. I am most grateful to Professor S. Ōmura of the Kitasato Institute, Tokyo, Japan, for the generous gift of cerulenin. 


\section{REFERENCES}

Asheshov, E. H. (1975). The genetics of tetracycline resistance in Staphylococcus aureus. Journal of General Microbiology 88, 132-140.

Avtalion, R. R., Zeigler-Schlomowitz, R., Perl, M., Wojdani, A. \& Sompolinsky, D. (i97i). Derepressed resistance to tetracycline in Staphylococcus aureus. Microbios 3, I 65-180.

Bligh, E. G. \& DYer, W. J. (1959). A rapid method of total lipid extraction and purification. Canadian Journal of Biochemistry and Physiology 37, 9I I-9I 7 .

Boldur, I. \& Sompolinsky, D. (1974). Antigen specific for bacteria resistant to tetracycline. Antimicrobial Agents and Chemotherapy 6, $117-120$.

Chopra, I., LACEy, R. W. \& Connolly, J. (1974). Biochemical and genetic basis of tetracycline resistance in Staphylococcus aureus. Antimicrobial Agents and Chemotherapy 6, 397-404.

D'Agnolo, G., Rosenfeld, I. S., Awaya, J., OMura, S. \& Vagelos, P. R. (1973). Inhibition of fatty acid synthesis by the antibiotic cerulenin. Biochimica et biophysica acta 326, I55-I 66.

De ZeEuw, J. R. (1968). Accumulation of tetracyclines by Escherichia coli. Journal of Bacteriology 95 , $498-506$.

Foster, T. J. \& Walsh, A. (1974). Phenotypic characterisation of R-factor tetracycline resistance determinants. Genetical Research 24, 333-343.

Franklin, T. J. (I967). Resistance of Escherichia coli to tetracyclines: changes in permeability to tetracyclines in Escherichia coli bearing transferable resistance factors. Biochenical Journal ro5, 371-378.

Franklin, T. J. \& Cook, J. M. (197I). R factor with a mutation in the tetracycline resistance marker. Nature, London 229, 273-274.

Goldberg, I., Walker, J. R. \& Bloch, K. (I973). Inhibition of lipid synthesis in Escherichia coli cells by the antibiotic cerulenin. Antimicrobial Agents and Chemotherapy 3, 549-554.

IZAKI, K., KIUCHI, K. \& ARIMA, K. (I 966). Specificity and mechanism of tetracycline resistance in a multiple drug resistant strain of Escherichia coli. Journal of Bacteriology 9r, 628-633.

KuCK, N. A. \& Forbes, M. (1973). Uptake of minocycline and tetracycline by tetracycline-susceptible and -resistant bacteria. Antimicrobial Agents and Chemotherapy 3, 662-664.

LACEY, R. W. \& ChOPRA, I. (1972). Evidence for mutation to streptomycin resistance in clinical strains of Staphylococcus aureus. Journal of General Microbiology 73, 175-1 80.

LEVY, S. B. \& MCMurRY, L. (1974). Detection of an inducible membrane protein associated with R-factormediated tetracycline resistance. Biochemical and Biophysical Research Communications 56, 1060-1068.

MACHTIGER, N. A. \& Fox, C. F. (1973). Biochemistry of bacterial membranes. Annual Review of Biochemistry 42, 575-600.

RANDALL, L. L. (1975). Insertion of a minor protein into the outer membrane of Escherichia coli during inhibition of lipid synthesis. Journal of Bacteriology 122, 347-35 I.

Shipley, P. L. \& OlSEN, R. H. (1974). Characteristics and expression of tetracycline resistance in Gramnegative bacteria carrying the Pseudomonas R factor RPI. Antimicrobial Agents and Chemotherapy 6, I $83-190$.

Sompolinsky, D., Krawitz, T., Zaidenzaig, Y. \& Abramova, N. (1970a). Inducible resistance to tetracycline in Staphylococcus aureus. Journal of General Microbiology 62, 34I-349.

Sompolinsky, D., Zaidenzaig, Y., Zeigler-Schlomowitz, R. \& Abramova, N. (1970 $b$ ). Mechanism of tetracycline resistance in Staphylococcus aureus. Journal of General Microbiology 62, 351-362. 